\title{
Apakah Media Audio Visual dapat Meningkatkan Kemampuan Menyimak?
}

\author{
Sutinah $^{(1)}$ \\ ${ }^{1}$ Guru SDN 2 Ngulankulon Kecamatan Pogalan Trenggalek \\ Email: ${ }^{1}$ sutinah1982@gmail.com, \\ DOI: https://doi.org/10.28926/riset_konseptual.v2i3.64
}

\begin{abstract}
ABSTRAK
Bahasa memilki peran sentral dalam perkembangan peserta didik dan merupakan penunjang keberhasilan dalam mempelajari semua bidang studi. Pembelajaran bahasa diharapkan membantu peserta didik mengenal jati dirinya dan budaya bangsa, mengemukakan pendapat dan perasan, berkomuniksi dalam masyarakat, dan menemukan serta mengunakan kemampuan menganalisis dan berimajinasi yang ada didalam dirinya. Tujuan diadakan penelitian ini meningkatkan keterampilan menyimak dongeng melalui Media Audio Visual dalam pembelajaran Bahasa Indonesia siswa Kelas III SDN 2 Ngulankulon Pogalan Trenggalek semester I Tahun pelajaran 2016/2017. Subjek dalam kegiatan penelitian ini adalah siswa Kelas III Semester I Tahun 2016/2017 yang siswanya berjumlah 23 siswa. Hasil penelitian yang dilakukan terbukti dengan peningkatan rata-rata Prestasi Belajar dari sebelum siklus yang hanya sebesar 60,9 ; pada siklus I naik menjadi 66,3 , dan pada siklus II naik menjadi 80,4. Ketuntasan belajar juga mengalami peningkatan. Dari sebelum siklus siswa yang mencapai ketuntasan belajar prasiklus ada $43,5 \%$ dan pada siklus I ada $60,9 \%$ dan siklus II $86,9 \%$.
\end{abstract}

Kata kunci: audio visual, menyimak

\section{PENDAHULUAN}

Pembelajaran Bahasa Indonesia diarahkan untuk meningkatkan kemampuan peserta didik untuk berkomunikasi dalam Bahasa Indonesia dengan baik dan benar, baik secara lisan maupun tulisan, serta menumbuhkan kemampuan berapresiasi terhadap hasil karya sastra. Pembelajaran sastra merupakan bagian dari pembelajaran Bahasa Indonesia yang dapat menumbuhkembangkan akal budinya melalui kegiatan pengalaman bersastra yang berupa apresiasi sastra, ekspresi sastra, dan kegiatan telah sastra, sehinga tumbuh suatu kemampuan untuk menghargai sastra sebagai sesuatu yang bermakna bagi kehidupan. Pembelajaran Bahasa Indonesia ditngkat SD dilaksanakan secara terpadu antara empat aspek keterampilan berbahasa, kebahasan dan sastra. Salah satu standar kompetensi tersebut adalah menyimak. Menurut Tarigan (2008:2) keterampilan berbahasa mencakup empat aspek, yaitu menyimak, berbicara, membaca, dan menulis. Menyimak merupakan keterampilan berbahasa awal yang dikuasai oleh manusia.

Keterampilan menyimak dongeng merupakan salah satu keterampilan berbahasa yang sangat penting. Keterampilan menyimak dongeng bertujuan untuk meningkatkan aspek komunikatif dan produktif. Peningkatan keterampilan menyimak dongeng perlu ditingkatkan dengan menggunakan pendekatan dan metode belajar yang tepat. Metode pembelajaran yang bukan hanya dapat mengkondisikan suasana pembelajaran, melainkan langkah intensif yang berhubungan langsung dengan kegiatan menyimak dongeng. Salah satu metode yang dapat digunakan dalam pembelajaran menyimak dongeng. Keterampilan menyimak menjadi dasar bagi kemampuan berbahasa lain. Sebagaimana menyatakan bahwa dengan meningkatkan kemampuan menyimak berarti pula membantu meningkatkan kualitas berbicara seseorang Tarigan (2008:3).

Media pembelajaran adalah semua bentuk perantara yang dipakai orang sebagai penyebar ide/gagasan, sehingga ide/gagasan itu sampai pada penerima. Media yang dimaksudkan adalah media yang penggunaannya diintegrasikan dengan 
tujuan dan isi pengajaran dan dimaksudkan untuk mempertinggi mutu mengajar dan belajar (Trianto, 2009:28). Leshin, Pollock dan Reigeuth mengklasifikasikan media ke dalam lima kelas, yaitu (1) media berbasis manusia (pengajar, instruktur, tutor, bermain peran, kegiatan kelas field trip); (2) media berbasis cetak (buku, buku latihan (workbook), dan modul); (3) media berbasis visual (buku, bagan, grafik, peta, gambar, transparansi, slide); (4) media berbasis audio visual (video, film, program, slide tape, dan televise); (5) media berbasis komputer (pengajaran dengan bantuan komputer, interaktif video, dan hypertext).

Alasan dibutuhkannya media pembelajaran (1) guru harus berusaha menyediakan materi yang mudah diserap siswa, (2) materi menjadi lebih mudah dimengerti apabila menggunakan alat bantu, dan (3) proses belajar mengajar memerlukan media dalam hal ini disebut media pembelajaran (Trianto, 2009:29). Manfaat media pembelajaran untuk menarik perhatian siswa terhadap materi yang disajikan, mengurangi bahkan menghilangkan verbalisme, membantu siswa memperoleh pengalaman belajar, membatasi keterbatasan ruang, waktu, lingkungan, terjadi kontak langsung antara siswa-guru, dan membantu mengatasi perbedaan pengalaman belajar berdasarkan latar belakang ekonomi siswa.

Sudjana (Subana, 2009:291) menyebutkan kriterianya, yaitu ketepatannya dengan tujuan pengajaran, dukungan terhadap isi bahan pengajaran, memberikan kemudahan, keterampilan guru dalam menggunakan waktu, dan sesuai dengan taraf berpikir siswa. Gagne (Trianto, 2009:10) bahwa pembelajaran yang efektif harus dilakukan dengan berbagai cara dan menggunakan berbagai macam media pembelajaran.

Menyimak adalah kegiatan mendengarkan lambang-lambang lisan yang dilakukan dengan sengaja, penuh perhatian disertai pemahaman, apresiasi, dan interpretasi untuk memperoleh pesan, informasi, memahami makna komunikasi, dan merespons yang terkandung dalam lambang lisan yang disimak (Tarigan, 2008:29). Menyimak merupakan kegiatan mendengarkan dengan penuh pemahaman, perhatian, apresiasi, dan interpretasi untuk memproleh informasi. Menangkap ide atau pesan serta memahami makna komunikasi yang telah disampakan oleh pembicara melalui ujaran atau bahasa lisan. Kegiatan menyimak berlangsung dengan konsep atau persiapan yang jauh lebih komplek dibandingkan dengan mendengar dan mendengarkan, keiatan menyimak melibatkan dua aktivitas sekaligus.

Mukhtar dan Anilawati (2006:3) mengatakan bahwa menyimak dapat diartikan sebagai suatu proses menyimak inporasi yang dilakukan melalui beberapa tahapan yaitu mendengarkan, memahami, menginterpretasi, menilai, dan memberikan respon terhadap apa yang disimak. Peristiwa menyimak melibatkan pendengaran, penglihatan, penghayatan, ingatan, pengertian, bahka hati nurani. Faisal (2005:11) mengatakan bahwa menyimak adalah kemampuan menangkap pesan yang disampaikan melalui bahasa lisan, menyimak adalah proses yang mencakup kegiatan mendengar bunyi bahasa, mengindentifikasi, menginterpretasi makna bunyi bahasa kemudian menilai dan menaggapi bunyi bahasa tersebut. Tujuan menyimak mendapatkan fakta, menganalisis pakta, mengevaluasi pakta, mendapatkan inpirasi, menghibur diri, meningkatkan kemampuan bicara. Tarigan (1997:88). Faktor-faktor yang mempengaruhi menyimak yaitu (1) faktor psikologis, (2) faktor fisik, (3) faktor pengalaman.

Media audio-visual adalah seperangkat alat yang dapat memproyeksikan gambar bergerak dan bersuara. Paduan antara gambar dan suara membentuk karakter sama dengan obyek aslinya (Sanaky, 2010:105). Sedangkan menurut Arsyad (2002:94) media berbasis audio visual adalah media visual yang mengandung penggunaan suara tambahan untuk memproduksinya. Kalau media visual hanya berupa buku, charts, grafik, gambar, dan sebagainya, tetapi media berbasis audio visual adalah media yang ditambah dengan suara sehingga media ini akan lebih berkesan terhadap siswa. Selain itu Sudjana dan Rivai (2003:58) mengemukakan bahwa media audio visual adalah sejumlah peralatan yang dipakai oleh para guru 
dalam menyampaikan konsep, gagasan dan pengalaman yang ditangkap oleh indera pandang dan pendengaraBerdasarkan pengertian-pengertian yang telah diberikan, maka media audiovisual adalah media penyalur pesan dengan memanfaatkan indera pendengaran dan penglihatan.

Menurut Idger Dale media audiovisual mempunyai potensi pokok memberikan dasar-dasar kongkrit untuk berfikir, membuat pelajaran lebih menarik, memungkinkan hasil belajar lebih tahan lama, memberikan pengalaman-pengalaman yang nyata, mengembangkan keteraturan dan kontinuitas berfikir, dapat memberikan pengalamanpengalaman yang tidak diperoleh dengan cara lain membuat kegiatan belajar lebih mendalam efisien dan beraneka ragam, dan media audio visual dapat dilakukan berulang-ulang. Beberapa hal yang harus diperhatikan dalam penggunaan audio-visual untuk pembelajaran yaitu guru harus mempersiapkan unit pelajaran terlebih dahulu, kemudian baru memilih media audio-visual yang tepat untuk mencapai tujuan pengajaran yang diharapkan, guru juga harus mengetahui durasi media audio-visual misalnya dalam bentuk film ataupun video, dimana keduanya yang harus disesuaikan dengan jam pelajaran, mempersiapkan kelas, yang meliputi persiapan siswa dengan memberikan penjelasan global tentang isi film, video atau televisi yang akan diputar dan persiapan peralatan yang akan digunakan demi kelancaran pembelajaran; aktivitas lanjutan, setelah pemutaran film atau video selesai, sebaiknya guru melakukan refleksi dan tanya jawab dengan siswa untuk mengetahui sejauh mana pemahaman siswa terhadap materi tersebut.

Kelebihan Media Audio Visual, antara lain memperjelas penyajian pesan agar tidak terlalu bersifat verbalistis (dalam bentuk kata-kata, tertulis atau lisan belaka); mengatasi keterbatasan ruang, waktu dan daya indera; siswa karena dapat mendengar dan melihat; variatif karena jenisnya beragam, guru dapat menggunakan beragam film yang ada kartun , tiga dimensi, empat dimensi, dan documenter; bisa diperlambat dan diulang, sehingga anak akan lebih jelas dan paham; dan papat digunakan tidak hanya untuk satu orang. Kelemahan media audiovisual, antara lain terlalu menekankan pentingnya materi daripada proses pengembangannya dan tetap memandang materi audio-visual sebagai alat bantu guru dalam mengajar; media audio visual cenderung menggunakan model komunikasi satu arah; media audio-visual tidak dapat digunakan dimana saja dan kapan saja, karena media audio-visual cenderung tetap di tempat dan dalam menggunakan video berarti memerlukan dua unit alat, yaitu VCD/DVD dan monitor TV, serta harganya relatif mahal; sering dianggap sebagai hiburan TV, dan kegiatan melihat video adalah kegiatan pasif.

\section{METODE}

Penelitian Tindakan Kelas yang digunakan untuk meningkatan kemampuan pemahaman konsep pasangan benda melalui media sepasang menara pada semester 2 tahun pelajaran 2016-2017 dipaparkan dalam bentuk siklus. Setiap siklus dilaksanakan satu kali pertemuan dengan alokasi waktu selama 2 jam pelajaran. Setiap siklus terdiri atas empat tahap, yaitu (1) tahap perencanaan. (2) tahap pelaksanaan atau tindakan, (3) tahap pengamatan atau observasi, dan (4) tahap refleksi. Selanjutnya masing-masing tahap dipaparkan seperti berikut ini.

\section{Rancangan Penelitian}

Tujuan penelitian yang telah dirumuskan dalam penelitian ini digunakan metode deskriptif kuantitatif untuk memecahkan masalah. Metode deskriptif merupakan salah satu metode yang digunakan untuk memperoleh salah satu gambaran secara objektif tentang objek penelitian (Surakhmad, 1990:139). Mmetode deskriptif kuantitatif ini (1) memusatkan diri pada masalah-masalah yang aktual, (2) data yang dikumpulkan mula-mula disusun, dijelaskan, dan kemudian dianalisis, (3) menjelaskan setiap langkah penyelidikan deskriptif itu dengan teliti dan terinci, (4) menjelaskan prosedur pengumpulan data, pengawasan, dan penilaian, dan (5) 
Vol. 2 No. 3, Juli 2018;

memberikan alasan yang kuat mengapa dalam metode deskriptif tersebut penyelidik memper $\neg$ gunakan teknik tertentu dan bukan teknik yang lain (Surakhmad, 1990:140).

\section{Perencanaan}

Tahap perencanaan kegiatan yang akan dilakukan adalah mempersiapkan beberapa perangkat yang berkenaan dengan kegiatan penelitian. Penyusunan perangkat pembelajaran yakni menyusun silabus, menyusun rencana pelaksanaan pembelajaran, dan menyusun lembar kerja peserta didik yang memuat tugas yang berkaitan dengan memahami teks eksposisii disertai langkah-langkah yang harus dilakukan oleh peserta didik. Penyusunan lembar observasi yang memuat aspek aktivitas peserta didik dalam pembelajaran yang digunakan oleh peneliti atau kolaborator. Penyusunan instrumen observasi terhadap kegiatan guru yang akan dilakukan oleh kolaborator. Instrumen observasi kegiatan guru memuat sejumlah pernyataan yang harus direspon oleh kolaborator dengan memberikan pernyataan ya atau tidak. Penyusunan instrumen-instrumen tersebut dilaksanakan di luar jam tatap muka sebelum dilangsungkannya penelitian.

\section{Pelaksanaan Tindakan}

Pelaksanaan tindakan dengan alokasi waktu selama 2 jam pelajaran. Kegiatan yang dilakukan pada tahap ini adalah melaksanakan pembelajaran dengan langkah-langkah yang sudah ditentukan. RPP sesuai dengan materi dan model pembelajaran. Menyusun LKS sesuai dengan materi. Menyiapkan sumber belajar sesuai dengan materi yang diajarkan. Menentukan media pembelajaran sesuai dengan materi. Menyusun soal evaluasi sesuai dengan materi. Dan enyusun format pengamatan keaktifan untuk menyimak dongeng melalui metode audio visual.

\section{Pengamatan}

Observasi kegiatan pembelajaran dilaksanakan saat pelaksanan proses pembelajaran untuk kegiatan inti berdasarkan Rencana Pelaksanaan Pembelajaran. Pengamatan dilakukan oleh observer dengan menggunakan pedoman observasi yang telah disusun oleh peneliti. Sedangkan yang diamati adalah segala aktivitas guru saat pembelajaran dan aktivitas siswa saat menggunakan metode audio visual dalam pembelajaran.

\section{Refleksi}

Tahap refleksi dilakukan setelah pelaksanaan pengamatan. Refleksi dilaksanakan dengan cara mencermati data yang diperoleh selama pengamatan (1) catatan guru tentang aktivitas peserta didik, (2) hasil observasi kegiatan peserta didik selama proses pembelajaran. Bila hasil refleksi belum menunjukkan hasil seperti yang ditetapkan dalam indikator keberhasilan yaitu $75 \%$ peserta didik memiliki motivasi tinggi, penelitian akan dilanjutkan ke siklus berikutnya.

Teknik Pengumpulan Data

Teknik pengumpulan data adalah cara yang digunakan oleh peneliti untuk memperoleh data yang diperluakan dalam penelitian. Adapun teknik pengumpulan data dalam penelitian ini dengan menggunakan tes, Observasi dengan dua instrumen pengamatan yakni aktivitas dan kreativitas siswa selama pembelajaran dan aktivitas guru selama kegiatan pembelajaran, dan dokumen berupa buku daftar nilai siswa kelas III tahun Pelajaran 2016/2017 yang berupa prestasi belajar siswa tentang menyimak dongeng.

\section{Teknik Analisis Data}

Penelitian dengan teknik analisis deskriptif kualitatif, yang bersifat menggambarkan kenyataan atau fakta sesuai dengan data yang diperoleh dengan tujuan untuk mengetahui prestasi belajar yang dicapai siswa selama proses 
Vol. 2 No. 3, Juli 2018;

pembelajaran. Analisis ini dihitung dengan menggunakan statistik sederhana yaitu analisis hasil tes, analisis hasil observasi, dan analisis indikator keberhasilan. Dalam penelitian ini memfokuskan kriteria tingkat keberhasilan atau ketuntasan secara klasikal, suatu kelas telah tuntas belajar jika sekurang-kurangnya $85 \%$ siswa telah tuntas belajar dengan ketentuan nilainya $\geq 70$.

\section{HASIL}

Berdasarkan hasil pengamatan pra siklus, guru terlalu mendominasi kegiatan belajar sehingga siswa kurang mandiri dan metode pembelajaran yang digunakan masih menggunakan cara lama yang membuat siswa menjadi bosan. Siswa hanya pasif mendengarkan materi yang disampaikan oleh guru. Siswa tidak tanggap dan kurang cekatan dalam menyelesaikan tugas yang diberikan. Hasil belajar siswa sangat rendah dan jauh dari standar kriteria ketuntasan minimal yang ditetapkan. Siswa yang mendapatkan nilai tuntas 10 siswa, tidak tuntas 13 siswa, dan nilai tertinggi 75 dan nilai terendah adalah 50 .

Hasil siklus I siswa yang mendapatkan nilai yang tuntas adalah sebanyak 14 siswa sedangkan siswa yang mendapatkan nilai yang tidak tuntas adalah sebanyak 9 siswa, dengan nilai tertinggi adalah 100 dan nilai terendah adalah 50 . Sesuai dengan indikator kinerjanya bahwa $75 \%$ siswa telah mengalami ketuntasan klasikal, maka pelaksanaan siklus I yang baru mencapai ketuntasan 60,9\% (belum berhasil), sehingga perlu dilakukan siklus II. Refleksi hasil evaluasi prestasi belajar diketahui belum tercapainya ketuntasan belajar, karena ketuntasan yang tercapai hanya 60,9\%. Beberapa hal penyebab adalah materi konsep dongeng sangat sulit, dongeng yang diberikan jarang didengar siswa, siswa yang duduk di belakang, tidak dapat melihat dengan media audiovisual

Hasil pada siklus II didapat nilai yang tuntas adalah sebanyak 20 siswa sedangkan siswa yang mendapatkan nilai yang tidak tuntas adalah sebanyak 3 siswa, dengan nilai tertinggi adalah 100 dan nilai terendah adalah 50. Sesuai dengan indikator kinerjanya bahwa $85 \%$ siswa telah mengalami ketuntasan individual, maka pelaksanaan siklus II yang telah mencapai ketuntasan $86,9 \%$ (berhasil), sehingga tidak perlu dilanjutkan pada siklus III. Refleksi berdasarkan diskripsi hasil tindakan II maka dapat dipaparkan analisis sebagai berikut pembelajaran pada tindakan II difokuskan agar siswa memahami konsep cerita dongeng melalui metode audiovisual. Tindakan pembelajaran sebagai upaya pemahaman siswa tentang menyimak dongeng melalui metode audiovisual. Berdasarkan observasi dari observer dan serangkaian pembelajaran tindakan II ditemukan beberapa hal sebagai berikut guru telah berupaya memperbaiki kelemahan-kelemahan yang terjadi pada siklus pertama, suasana belajar lebih interaktif, siswa terihat lebih antusias dalam mengerjakan tugas yang diberikan oleh guru, interaktif yang terjadi multi arah, tidak hanya guru dengan siswa, tetapi juga antara siswa dengan siswa, kemampuan guru dalam mengimplementasikan metode audiovisual telah maksimal, dan guru telah berusaha agar siswa yang kurang pandai, berani bertanya dan mengeluarkan pendapat.

Berdasarkan hasil penelitian dan refleksi masing-masing siklus dapat ditarik kesimpulan bahwa indikator penelitian tindakan yang terdiri atas guru terampil mengelola proses belajar mengajar dengan menggunakan metode audiovisual, terjadi interaksi aktif antara guru dengan siswa, siswa dengan siswa sehingga proses belajar mengajar dapat kondusif, dan 86,9\% siswa kelas III SDN 2 Ngulankulon Kecamatan Pogalan Kabupaten Trenggalek Semester 1 Tahun Pelajaran 2016/2017 mampu memahami dan melaksanakan proses pemahaman konsep menyimak dongeng melalui metode audiovisual, dapat terwujud.

\section{PEMBAHASAN}

Prestasi Belajar yang di dapat dari penelitian tindakan kelas terhadap siswa Kelas III SDN 2 Ngulankulon Pogalan Trenggalek pada mata Pelajaran Bahasa Indonesia materi menceritakan isi dongeng menunjukkan peningkatan yang baik. 
Vol. 2 No. 3, Juli 2018;

Terbukti dengan peningkatan rata-rata Prestasi Belajar dari sebelum siklus yang hanya sebesar 60,9 ; pada siklus I naik menjadi 66,3 , dan pada siklus II naik menjadi 80,4 . Ketuntasan belajar juga mengalami peningkatan. Dari sebelum siklus siswa yang mencapai ketuntasan belajar prasiklus ada 43,5\% dan pada siklus I ada 60,9 \% dan siklus II 86,9\%. Dengan demikian pembelajaran melalui Penelitian Tindakan Kelas (PTK) guru akan melakukan analisis terhadap tugasnya sendiri di dalam kelas, selanjutnya bisa, selanjutnya bisa menemukan kelebihan dan kekurangan yang kemudian mengembangkan alternatif untuk mengatasi kelemahannya, meskipun sebenarnya peneliti merasa kesulitan untuk mengatasi bermacam - macam karakter siswa, tetapi juga merasa puas karena bisa memperbaiki dan mengatasi kinerjanya sebagai guru dalam mengatasi kesulitan belajar siswa dalam proses pembelajaran. Dengan demikian dapat dikatakan bahwa penelitian tindakan kelas terhadap siswa kelas III SDN 2 Ngulankulon Trenggalek, pada pembelajaran Bahasa Indonesia melalui media audio visual telah berhasil meningkatkan motivasi dan Prestasi Belajar siswa.

\section{KESIMPULAN}

Berdasarkan hasil penelitian yang telah dilaksanakan selama 3 bulan, maka dapat ditarik kesimpulan bahwa Keterampilan dalam menyimak dongeng siswa Kelas III SDN 1 Ngulankulon Trenggalek mengalami peningkatan setelah pembelajaran dengan media audio visual diterapkan pada bidang studi Bahasa Indonesia. Terbukti dengan peningkatan rata-rata Prestasi Belajar dari sebelum siklus yang hanya sebesar 60,9 ; pada siklus I naik menjadi 66,3, dan pada siklus II naik menjadi 80,4. Ketuntasan belajar juga mengalami peningkatan. Dari sebelum siklus siswa yang mencapai ketuntasan belajar prasiklus ada $43,5 \%$ dan pada siklus I ada $60,9 \%$ dan siklus II 86,9\%.

\section{SARAN}

Perlu dicoba melakukan kombinasi pola pembelajaran yang menggunakan Media Audio Visual dengan model belajar yang lain. Untuk meningkatkan kemampuan siswa dalam memahami materi ajar dalam kegiatan penelitian ini, maka siswa menjawab pertanyaan--pertanyaan dengan diberi test tertulis atau tugas lainnya. Perlu diberikan pelatihan untuk meningkatkan kemampuan guru dalam mengembangkan model pembelajaran yang menggunakan Media Audio Visual agar guru dapat mengembangkan kemampuannya untuk menerapkan pada pokok bahasan lain. Selain itu juga dapat menularkan pengalaman yang diperolehnya ini kepada guru yang lain. Penggunaan model pembelajaran dengan menggunakan Media Audio Visual perlu terus dilakukan karena pembelajaran ini lebih menyenangkan bagi siswa, mendorong dan membiasakan siswa untuk belajar mandiri, tidak bergantung kepada guru.

\section{DAFTAR RUJUKAN}

Ahmad Rivai, Nana Sudjana. 2003. Media Pengajaran. Bandung: Sinar Baru Algensindo.

AH Sanaky, Hujair. 2010. Media Pembelajaran. Buku Pegangan Wajib Guru Dan Dosen. Yogyakarta: Kaukaba Dipantara.

Alton, Wells M. 1987. College English. New York: Harcourt: Brace and World, Inc.

Anilawati. Khahlil Mukhtar. 2006. Menyimak. Pekanbaru: Cendikia Insani

Arsyad, A. 2002. Media Pembelajaran. Jakarta: Raja Grafindo Persada.

Faisal. Sanapiah. 2005. Metodologi Penelitian Pendidikan. Surabaya: Usaha Nasional.

Sudjana. Nana. 2009. Penilaian Hasil Proses Belajar Mengajar. Bandung: PT Remaja Rosdakarya.

Surakhmad, Winarno. 1990. Pengantar Penelitian IImiah. Bandung: Tarsito.

Tarigan, Henry Guntur. 1997. Menyimak Sebagai Suatu Keterampilan Berbahasa. Angkasa Bandung.

Tarigan, Henry Guntur. 2008. Membaca Sebagai Suatu Keterampilan Berbahasa. Bandung: Angkasa 
JURNAL PENDIDIKAN: Riset \& Konseptual

E-ISSN: 2598-2877

http://journal.unublitar.ac.id/pendidikan/index.php/Riset_Konseptual

P-ISSN: 2598-5175

Vol. 2 No. 3, Juli 2018;

Trianto, 2009 Mendesain Model Pembelajaran Inovatif-Progresif. Jakarta Kencana Prenada Group. 